\section{Establishment, Growth, and Foliar Nutrient Content of Plum Trees on Various Rootstocks}

\author{
G.E. Boyhan', J.D. Norton ${ }^{2}$, and J.A. Pitts ${ }^{3}$ \\ Department of Horticulture and Alabama Agricultural Experiment Station, \\ Auburn University, AL 36849
}

Additional index words. Prunus persica, Prunus insititia, nutrition, rootstock

\begin{abstract}
The dwarfing characteristics of St. Julien and Pixy rootstocks, measured by shoot growth, were evident with 'AU-Amber' and 'AU-Producer' plum (Prunus salicina Lindl.) scions. Dwarfing did not occur with 'AU-Rubrum'. Trunk cross-sectional area (TCA) was reduced with 'AU-Amber', 'AU-Producer', and 'AU-Rubrum' scions on St. Julien and Pixy rootstocks. After 3 years, tree survival was $\mathbf{9 4 \%}$ for Lovell; 89\%, Halford; $57 \%$, Nemaguard; $75 \%$, Nemared; $83 \%$, St. Julien; and 47\%, Pixy. Tree survivability was significantly lower on Nemaguard and Pixy rootstocks than on Lovell and Halford. Multiple regression of total shoot growth, TCA, and survivability against foliar nutrient content resulted in the following significant equations: $0.460 \mathrm{Mg}-0.210 \mathrm{Mn}, 0.236 \mathrm{~B}$ $0.487 \mathrm{Mn}$, and $0.359 \mathrm{~N}+0.398 \mathrm{Ca}-0.267 \mathrm{P}-0.360 \mathrm{Fe}$ for each, respectively. Growth, survivability, and foliar nutrient content are significantly affected by rootstock in plum production.
\end{abstract}

Many fruit crops are grafted onto rootstocks for asexual propagation, which offers a quick and efficient method of maintaining trees true to type for a particular cultivar. Rootstocks, however, can have profound effects on scions, such as controlling plant height, time of flowering, cold hardiness, disease resistance, and nutritional composition of the plant (Dozier et al., 1983, 1984; Hartmann and Kester, 1975; Knowles et al., 1984; Misic, 1990; Okie, 1990). Several different rootstocks are available for plums (Prunus spp.), including seedling and asexually propagated material.

Most plum rootstocks are regionally adapted; rootstocks from other parts of the world are different from those commonly used in the southeastern United States (Rom and Carlson, 1982). The Japanese plum cultivars common to North America are grown on several rootstocks including Myrobalan 29C, Marianna 2624, Nemaguard, Lovell, and Halford. The latter two are peach (P. persica L. Batsch) seedling rootstocks common to the southeastern United States (Rom and Carlson, 1982). 'Nemaguard' is a P. persica $\times P$. davidiana hybrid (Hesse, 1975). Nemared is a red-leafed seedling rootstock similar to Nemaguard in rootstock characteristics, including resistance to root-knot nematodes [Meloidogyne incognita (Kofoid and white)] and chitwood [M. javanica (Treub) Chitwood] (Rom and Carlson, 1982).

\footnotetext{
Received for publication 27 June 1994. Accepted for publication 12 Dec. 1994. Alabama Agricultural Expt. Station publication no. 11-944810O. The cost of publishing this paper was defrayed in part by the payment of page charges. Under postal regulations, this paper therefore must be hereby marked advertisement solely to indicate this fact.

'Senior Research Associate.

${ }^{2}$ Professor.

${ }^{3}$ Superintendent.
}

Dwarfing rootstocks are also available. Two such dwarfing rootstocks are St. Julien A and Pixy, which are clonal material of $P$. insititia L. (Cummins and Aldwinckle, 1983; Hartmann and Keter, 1975). Scholtens and Wertheim (1990) found no advantage in 10 dwarfing rootstocks over St. Julien A using 'Victoria' as the scion.

Incompatibility is an important criterion in rootstock selection. There have been incompatibilities between '2977AD' (a new clonal plum rootstock) and the 'Martin' plum and some other Prunus species in long-term studies (Tabuenca and Moreno, 1988).

Extensive studies of rootstock effects on peaches have been performed in the southeastern United States. In studies of 'Loring' peach on Lovell, Elberta, and Vila Fria rootstocks, Dozier et al. (1983) found that 'Lovell' had the best yield on a per land area basis and had equivalent survivability to Elberta. Vila Fria was unacceptable due to low survival and yield. Dozier et al. (1984) found that Siberian $\mathrm{C}$ was an unacceptable rootstock due to low survival and fruit yield. Furthermore, they found that Nemaguard, although promoting vigorous growth and resistance to root-knot nematode, was highly susceptible to ring nematode [Criconemella xenoplax (Raski) Luc and Raski]. Finally, they concluded that Halford and Lovell were best for replanting southern peach orchards prone to peach tree short life.

Fruit quality and yield can be influenced by nutrient levels in the plant, which also can be affected by rootstock. Knowles et al. (1984) found that the rootstock Siberian C was correlated with lower $\mathrm{Ca}$ levels, particularly important in maintaining fruit quality, in 'Loring' and 'Redhaven' peach scions. Measurements of $\mathrm{N}, \mathrm{K}, \mathrm{Ca}, \mathrm{Zn}$, and $\mathrm{Mn}$ in Italian prune (Prunus domestica L.) leaves was lower on peach rootstock then on St. Julien A rootstock (Westwood, 1993). Furthermore, plum clones
Myrobalan 29C, Myrobalan B, and St. Julien A were more efficient in Ca uptake than other plum and peach rootstocks (Westwood, 1993).

Soil type can have an important influence on rootstock and therefore rootstock selection. Myrobalan and Marianna plum rootstocks tolerate heavy soils better than peach rootstocks (Westwood, 1993).

Plant nutrient content and its effect on the tree can be a complex situation in which one nutrient can influence the concentration of another. Sanchez-Alonso and Lachica (1987) found that Mn deficiency affects efficient $\mathrm{N}$ metabolism in the 'Golden Japan' plum. This was studied further by Reeves et al. (1985) who found chlorosis caused by high Ca levels in growing solutions was correlated best with high foliar $\mathrm{P}: \mathrm{Fe}$ and $\mathrm{P}: \mathrm{Zn}$ ratios among the plum rootstocks tested. Studies with prunetype plums indicated a positive correlation between $\mathrm{N}$ uptake and $\mathrm{Ca}, \mathrm{Mg}, \mathrm{B}$, and $\mathrm{Zn}$ uptake (Westwood, 1993). There was also a correlation $\mathrm{Ca}$ uptake and $\mathrm{Mg}$ or $\mathrm{B}$ uptake (Westwood, 1993).

Because rootstock has such an important fundamental effect on scion performance, our study evaluates rootstock effects on establishment and early performance of plum cultivars adapted to the southeastern United States.

\section{Materials and Methods}

Rootstocks chosen for this study included Lovell, Halford, Nemaguard, Nemared, St. Julien A, and Pixy. Scion cultivars used in this study included 'AU-Amber', 'AU-Producer', 'AU-Rosa', and 'AU-Rubrum'. The trees were obtained from Cumberland Valley Nursery, McMinnville, Tenn. This experiment was arranged in a randomized complete-block design. Not all rootstock-scion combinations were included; therefore, it was not possible to address rootstock $\mathbf{x}$ scion interactions. Consequently, rootstock data are presented for each cultivar separately. There were six single-tree replications. The soil at the planting site was a Rustin fine sandy loam and was prepared according to Alabama Agricultural Expt. Station soil test recommendations with trees spaced $3 \mathrm{~m}$ in the row and $6.1 \mathrm{~m}$ between rows. One-year-old budded whips were planted in Winter 1989 and were trained to an opencenter tree form. Measurements included current shoot growth, trunk diameter, and tree survival, which were recorded in Fall 1990 through 1993. Current shoot growth was the average of five terminal shoots measured at random on each tree. Trunk diameter was measured $30 \mathrm{~cm}$ above ground level. Dead trees were noted each year at the time growth measurements were taken. Trees that died in 1990 were not counted, thus each cultivar began the test with $100 \%$ survivability. This was done to minimize cultural practice bias and to reflect more closely rootstock effects on survival.

From the midpoint ofcurrent-year's growth, mature leaves were collected in Aug. 1991 and 1992 from each tree. These samples were analyzed for total $\mathrm{N}$ by a modified microKjeldahl method with a selenium catalyst 
(Baker and Thompson, 1992). Phosphorus, K, $\mathrm{Ca}, \mathrm{Mg}, \mathrm{Mn}, \mathrm{Fe}, \mathrm{B}$, and $\mathrm{Zn}$ concentrations were determined using an inductively coupled argon-plasm spectrophotometer (Donohue and Aho, 1992).

Statistical analysis was conducted using Systat 5.2.1. Multiple linear regression analysis was done in a backward stepwise fashion, with the probability to enter or remove a predictor set to 0.05 and the tolerance set to 0.1 (Wilkinson et al., 1992).

\section{Results and Discussion}

\section{Growth}

'AU-Amber'. In 1990, 'AU-Amber' shoot growth was similar for all rootstocks. In 1991, its shoot growth was significantly lower on St. Julien and Pixy than on Lovell, Halford, Nemaguard, and Nemared (Table 1). Shoot growth in 1992 was similar on all rootstocks. In 1993, however, shoot growth on St. Julien was significantly lower than on Nemared. Finally, the increase in trunk cross-sectional area (TCA) over 3 years was significantly lower on St. Julien or Pixy than on other rootstocks.

'AU-Producer' In 1990, 'AU-Producer' shoot growth was significantly higher on St. Julien than on Love11 or Pixy. This was somewhat reversed in 1991, with shoot growth being greater on Lovell and Nemaguard than on St. Julien and Pixy. Shoot growth in 1992 was lower on St. Julien than on Lovell or Halford, and in 1993, it was lower than on Nemared. The 3-year TCA increase was significantly lower on Pixy than on Lovell, Halford, Nemaguard, and Nemared but did not differ from that of St. Julien (Table 1).

'AU-Rosa'. In 1990 and 1992, shoot growth was not affected by rootstock. In 1991, however, shoot growth was significantly greater for scions on Nemared than on Nemaguard, and in 1993, shoot growth was greater with scions on Nemared or Nemaguard compared to those on Halford. The 3-year TCA increase was not affected by the four rootstocks evaluates with 'AU-Rosa'.

'AU-Rubrum'. Nemaguard was not included as a rootstock with 'AU-Rubrum', and there were no differences in shoot growth for any year among the remaining rootstocks (Table 1). Final TCA increase, however, was significantly lower with St. Julien and Pixy than with Nemared.

After 3 years, tree survival on Nemaguard and Pixy was significantly lower than on Lovell or Halford, with most deaths on Nemaguard occurring in the first year, whereas those on Pixy occurred over 2 years (Fig. 1).

Although neither shoot growth nor increase in TCA was controlled in every year with each cultivar, in the aggregate, Pixy and St. Julien were dwarfing. Dwarfing can be an important characteristic in fruit tree production. If fruit productivity per length of shoot or tree longevity are not decreased relative to vigorous trees, dwarfing allows more trees per unit area and may increase the amount of fruiting wood for the same unit of area. This aspect has been explored and exploited more fully with other fruit trees, most notably apples (Malus domestica Borkh.). Our study suggests that the rootstocks may reduce growth of plum cultivars in some years, but effects on fruit yield, yield efficiency, and fruit quality have not been evaluated. However, in this study possible dwarfing effects are offset by the high death rate for Pixy. With $83 \%$ surviving after 3 years, St. Julien may be a better rootstock candidate for high-density plum plantings.

\section{Nutrients}

There were no significant foliar nutrient level $\mathrm{x}$ year interactions for any of the elements measured; therefore, the analysis was conducted on data combined for the two years.

'AU-Amber'. 'AU-Amber' exhibited no difference in foliar N, P, Fe, B, or Zn based on rootstock. Potassium levels were significantly higher on Pixy rootstock compared to Nemaguard or Nemared (Table 2). Calcium and $\mathrm{Mg}$ were significantly lower on Pixy and St. Julien compared to Lovell, Halford, or Nemaguard. Manganese levels were higher on Pixy than on all but St. Julien.

'AU-Producer'. 'AU-Producer' had higher levels of $\mathrm{P}$ on Pixy than on all rootstocks but St. Julien; it had higher K levels on Pixy and St. Julien than on Nemaguard, Halford, or Lovell. Calcium levels were lower on Pixy than on Nemaguard or St. Julien. Magnesium was lower on Pixy than on all rootstocks but St. Julien. Iron concentrations were lower on Pixy than St. Julien. Boron was higher in foliage of 'AU-Producer' grafted on Lovell than on

Table 1. Plum shoot growth and increase in trunk cross-sectional area (TCA) from 1990 to 1993

\begin{tabular}{|c|c|c|c|c|c|}
\hline \multirow[b]{2}{*}{ Rootstock } & \multicolumn{4}{|c|}{ Shoot growth $(\mathrm{cm})$} & \multirow{2}{*}{$\frac{\text { TCA }\left(\mathrm{cm}^{2}\right)}{1990-93}$} \\
\hline & 1990 & 1991 & 1992 & 1993 & \\
\hline \multicolumn{6}{|c|}{$A U$-Amber } \\
\hline Lovell & $47 a^{z}$ & $164 \mathrm{a}$ & 89 a & $54 \mathrm{ab}$ & $196 \mathrm{a}$ \\
\hline Halford & $58 \mathrm{a}$ & $135 \mathrm{a}$ & $82 \mathrm{a}$ & $57 \mathrm{ab}$ & $170 \mathrm{a}$ \\
\hline Nemaguard & $49 \mathrm{a}$ & $146 \mathrm{a}$ & $79 a$ & $59 \mathrm{ab}$ & $209 \mathrm{a}$ \\
\hline Nemared & $55 \mathrm{a}$ & $132 \mathrm{a}$ & $87 \mathrm{a}$ & $63 \mathrm{a}$ & $169 \mathrm{a}$ \\
\hline St. Julien & $44 \mathrm{a}$ & $98 \mathrm{~b}$ & $72 \mathrm{a}$ & $47 \mathrm{~b}$ & $85 \mathrm{~b}$ \\
\hline Pixy & 36 a & $86 \mathrm{~b}$ & $72 \mathrm{a}$ & $51 \mathrm{ab}$ & $79 \mathrm{~b}$ \\
\hline \multicolumn{6}{|c|}{ AU-Producer } \\
\hline Lovell & $43 \mathrm{bc}$ & $142 \mathrm{ab}$ & $102 \mathrm{a}$ & $55 \mathrm{ab}$ & $119 \mathrm{ab}$ \\
\hline Halford & $51 \mathrm{ab}$ & $124 \mathrm{a}-\mathrm{c}$ & $102 \mathrm{a}$ & $54 \mathrm{ab}$ & $158 \mathrm{a}$ \\
\hline Nemaguard & $48 \mathrm{a}-\mathrm{c}$ & $142 \mathrm{a}$ & $96 \mathrm{ab}$ & $49 a b$ & $123 \mathrm{ab}$ \\
\hline Nemared & $45 \mathrm{a}-\mathrm{c}$ & $133 \mathrm{a}-\mathrm{c}$ & $84 a b$ & $61 \mathrm{a}$ & $104 \mathrm{~b}$ \\
\hline St. Julien & $62 \mathrm{a}$ & $97 \mathrm{c}$ & $49 \mathrm{~b}$ & $45 \mathrm{~b}$ & $97 \mathrm{bc}$ \\
\hline Pixy & $31 \mathrm{c}$ & $110 \mathrm{bc}$ & $65 a b$ & $53 a b$ & $41 \mathrm{c}$ \\
\hline \multicolumn{6}{|c|}{$A U-\operatorname{Ros} a$} \\
\hline Lovell & $54 \mathrm{a}$ & $141 \mathrm{ab}$ & 98 a & $54 \mathrm{ab}$ & $136 \mathrm{a}$ \\
\hline Halford & $62 \mathrm{a}$ & $142 \mathrm{ab}$ & $76 \mathrm{a}$ & $46 \mathrm{~b}$ & $98 \mathrm{a}$ \\
\hline Nemaguard & $56 \mathrm{a}$ & $105 \mathrm{~b}$ & $76 \mathrm{a}$ & $58 \mathrm{a}$ & $138 \mathrm{a}$ \\
\hline Nemared & $50 \mathrm{a}$ & $167 \mathrm{a}$ & $72 \mathrm{a}$ & $67 \mathrm{a}$ & $101 \mathrm{a}$ \\
\hline \multicolumn{6}{|c|}{ AU-Rubrum } \\
\hline Lovell & $45 \mathrm{a}^{2}$ & $80 \mathrm{a}$ & 71 a & $64 \mathrm{a}$ & $81 \mathrm{ab}$ \\
\hline Halford & $39 \mathrm{a}$ & $109 a$ & $79 \mathrm{a}$ & $47 \mathrm{a}$ & $73 a b$ \\
\hline Nemared & $43 \mathrm{a}$ & $70 \mathrm{a}$ & $69 \mathrm{a}$ & $53 \mathrm{a}$ & $111 \mathrm{a}$ \\
\hline St. Julien & $33 \mathrm{a}$ & $90 \mathrm{a}$ & $57 \mathrm{a}$ & $51 \mathrm{a}$ & $47 \mathrm{~b}$ \\
\hline Pixy & $40 \mathrm{a}$ & $90 \mathrm{a}$ & $70 \mathrm{a}$ & $42 \mathrm{a}$ & $23 \mathrm{~b}$ \\
\hline
\end{tabular}

${ }^{2}$ Means followed by the same letter within a column for a cultivar are not significantly different by Fisher's least significant differences at $P \leq 0.05$.

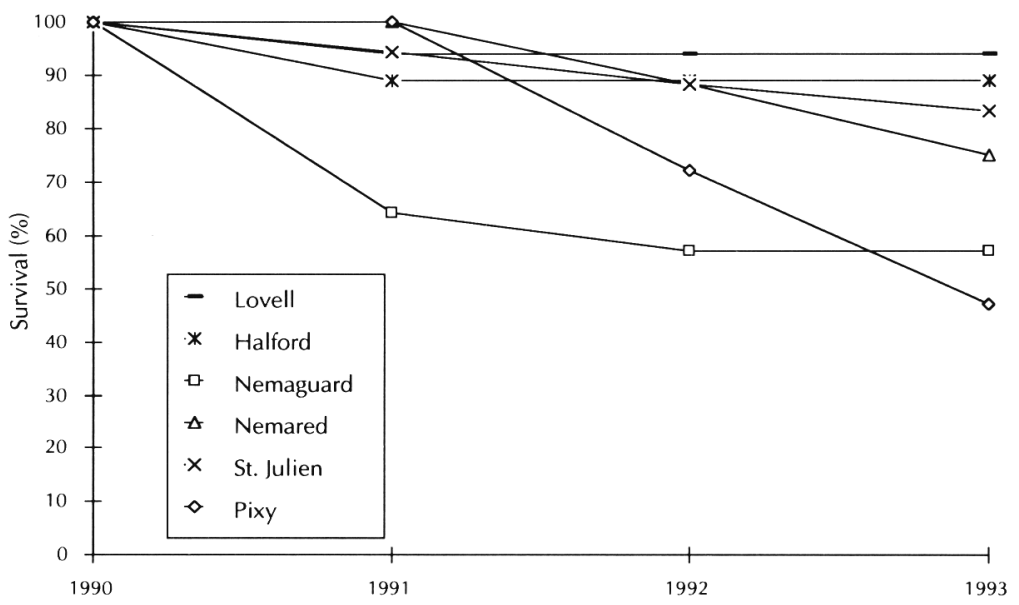

Fig. 1. Tree survival by rootstocks. Mean separation for 1993 by Fishers' protected least significant difference at $P \leq 0.05$. Lovell, 94 a; Halford, 89 a; St. Julien, 83 ab; Nemared, 75 a-c; Nemaguard, 57 bc; Pixy, 47 c. 
trees grafted to Nemared, St. Julien, and Pixy.

'AU-Rosa'. 'AU-Rosa' grafted on Halford had higher foliar $\mathrm{P}$ concentrations than when grafted on Nemaguard or Nemared. Also, K levels were higher on Halford than on Nemaguard. Calcium levels were higher on Halford and Nemaguard than on Nemared. Foliage Mg levels were higher on Lovell and Halford than on Nemaguard and Nemared. Finally, $\mathrm{Zn}$ levels on Halford were higher than on Lovell, Nemaguard, or Nemared.

'AU-Rubrum'. 'AU-Rubrum' foliage $\mathrm{N}$ levels were higher on St. Julien than on Lovell or Pixy. On St. Julien rootstock, 'AU-Rubrum' had higher $\mathrm{K}$ levels than on all other rootstocks (Table 2). Calcium levels were significantly lower on Pixy than on Nemared or St. Julien. Magnesium levels on St. Julien and Pixy were significantly lower than on Halford or Nemared. Also, Mn levels were higher on St. Julien and Pixy than on the other rootstocks (Table 2).

None of the nutrient concentrations measured in this study were below or above the normal range for the nutrient in question for plums (Childers, 1983; Westwood, 1993). To better clarify the relationship between foliar nutrient levels and growth and survivability, multiple linear regression was conducted with the foliar nutrient levels as the predictors of total shoot growth for 1990 to 1993, TCA, and survival (Table 3). A stepwise analysis indicated that $\mathrm{Mg}$ and $\mathrm{Mn}$ were positive and negaThe $R^{2}$ value indicated that $\approx 32 \%$ of the variability in total shoot growth is predicted by the applicable equation (Table 3). Of TCA, $\approx 34 \%$ was predicted by changes in $\mathrm{Mn}$ and $\mathrm{B}$. Finally, $\mathrm{N}$ and $\mathrm{Ca}$ as positive predictors and $\mathrm{P}$ and $\mathrm{Fe}$ as negative predictors accounted for $\approx 30 \%$ of the survivability in plum trees in this study. tive predictors of shoot growth, respectively.

Calcium levels, which have been implicated in peach tree survival are of particular interest (Knowles et al., 1984). Calcium levels were lower on Pixy than on other rootstocks but not always significantly so. This low concentration may be partially responsible for the high death rate of trees on Pixy rootstock. These results are similar to those with peaches, where there was a positive correlation between $\mathrm{Ca}$ levels and tree survival (Knowles et al., 1984). This factor does not explain the high death rate of Nemaguard, which led to relatively high $\mathrm{Ca}$ levels in scion leaves. In studies on prunes, the correlation between $\mathrm{N}$ and $\mathrm{Ca}$ (Westwood, 1993) is particularly interesting in regard to our study: these two elements were important predictors of tree survival.

Knowles et al. (1984) also found a correlation between low $\mathrm{K}$ concentrations and poor survival. This relationship was not present with scions on Pixy rootstock, which had relatively high K levels; however, Nemaguard, which had low foliar $\mathrm{K}$ levels (not always significantly so), also had low survival.

Although these equations are significant in predicting total shoot growth, TCA, and survival, we cannot offer any satisfactory explanation for these results, which should be interpreted as exploratory. More elaborate experiments are required to fully characterize the relationship between foliar nutrient content and these growth characteristics.

Based on this study, Nemaguard and Pixy should not be used as rootstocks for plum in the southeastern United States because of poor survival. Further study of yield, survival, and tree growth will have to be conducted before alterations of current recommendations concerning plum rootstocks can be made and the continued widespread practice of using seedling peach rootstocks is altered.

Table 2. Rootstock effect on foliar nutrient content of plum cultivars.

\begin{tabular}{|c|c|c|c|c|c|c|c|c|c|}
\hline \multirow[b]{2}{*}{ Cultivar } & \multicolumn{4}{|c|}{ Dry wt (\%) } & \multicolumn{5}{|c|}{ Dry wt (ppm) } \\
\hline & $\mathrm{N}$ & $\mathrm{P}$ & $\mathrm{K}$ & $\mathrm{Ca}$ & $\mathrm{Mg}$ & $\mathrm{Mn}$ & $\mathrm{Fe}$ & $\mathrm{B}$ & $\mathrm{Zn}$ \\
\hline \multicolumn{10}{|c|}{$A U-A m b e r$} \\
\hline Lovell & $2.24 \mathrm{a}^{2}$ & $0.15 \mathrm{a}$ & $2.05 \mathrm{a}-\mathrm{c}$ & $1.40 \mathrm{a}$ & $0.41 \mathrm{a}$ & $48 \mathrm{bc}$ & $110 \mathrm{a}$ & $82 a$ & $23 a$ \\
\hline Halford & $2.39 \mathrm{a}$ & $0.14 \mathrm{a}$ & $2.04 \mathrm{a}-\mathrm{c}$ & $1.35 \mathrm{a}$ & $0.38 \mathrm{a}$ & $38 \mathrm{c}$ & $114 a$ & $67 \mathrm{a}$ & $32 \mathrm{a}$ \\
\hline Nemaguard & $2.33 \mathrm{a}$ & $0.15 \mathrm{a}$ & $1.87 \mathrm{c}$ & $1.46 \mathrm{a}$ & $0.38 \mathrm{a}$ & $42 \mathrm{bc}$ & $106 \mathrm{a}$ & $72 \mathrm{a}$ & $25 \mathrm{a}$ \\
\hline Nemared & $2.47 \mathrm{a}$ & $0.16 \mathrm{a}$ & $1.89 \mathrm{bc}$ & $1.26 \mathrm{ab}$ & $0.36 \mathrm{a}$ & $42 \mathrm{c}$ & $113 \mathrm{a}$ & $67 \mathrm{a}$ & $32 \mathrm{a}$ \\
\hline St. Julien & $2.53 \mathrm{a}$ & $0.16 \mathrm{a}$ & $2.16 a b$ & $1.03 \mathrm{~b}$ & $0.27 \mathrm{~b}$ & $86 a b$ & $94 \mathrm{a}$ & $65 a$ & $31 \mathrm{a}$ \\
\hline Pixy & $2.32 \mathrm{a}$ & $0.18 \mathrm{a}$ & $2.26 \mathrm{a}$ & $0.86 \mathrm{~b}$ & $0.26 \mathrm{~b}$ & $106 \mathrm{a}$ & $92 \mathrm{a}$ & $64 \mathrm{a}$ & $30 \mathrm{a}$ \\
\hline \multicolumn{10}{|c|}{ AU-Producer } \\
\hline Lovell & $2.41 \mathrm{a}$ & $0.19 \mathrm{~b}$ & $1.88 \mathrm{c}$ & $1.48 \mathrm{a}-\mathrm{c}$ & $0.40 \mathrm{a}$ & $50 \mathrm{a}$ & $84 \mathrm{~b}$ & $85 \mathrm{a}$ & $30 \mathrm{a}$ \\
\hline Halford & $2.45 \mathrm{a}$ & $0.19 \mathrm{~b}$ & $2.03 \mathrm{c}$ & $1.48 \mathrm{a}-\mathrm{c}$ & $0.38 \mathrm{ab}$ & $45 \mathrm{a}$ & $81 \mathrm{~b}$ & $58 \mathrm{ab}$ & $28 \mathrm{a}$ \\
\hline Nemaguard & $2.28 \mathrm{a}$ & $0.18 b$ & $1.90 \mathrm{c}$ & $1.84 \mathrm{a}$ & $0.42 \mathrm{a}$ & $52 \mathrm{a}$ & $113 \mathrm{ab}$ & $56 \mathrm{ab}$ & $30 \mathrm{a}$ \\
\hline Nemared & $2.44 \mathrm{a}$ & $0.20 \mathrm{~b}$ & $2.07 \mathrm{bc}$ & $1.34 \mathrm{bc}$ & $0.38 \mathrm{ab}$ & $58 \mathrm{a}$ & $105 a b$ & $50 \mathrm{~b}$ & $27 \mathrm{a}$ \\
\hline St. Julien & $2.45 \mathrm{a}$ & $0.22 a b$ & $2.39 \mathrm{a}$ & $1.52 \mathrm{ab}$ & $0.32 \mathrm{bc}$ & $57 \mathrm{a}$ & $128 \mathrm{a}$ & $46 \mathrm{~b}$ & $30 \mathrm{a}$ \\
\hline Pixy & $2.36 \mathrm{a}$ & $0.24 \mathrm{a}$ & $2.33 \mathrm{ab}$ & $1.11 \mathrm{c}$ & $0.28 \mathrm{c}$ & $70 \mathrm{a}$ & $93 \mathrm{~b}$ & $44 \mathrm{~b}$ & $33 a$ \\
\hline \multicolumn{10}{|c|}{$A U-\operatorname{Ros} a$} \\
\hline Lovell & $2.59 \mathrm{a}^{\mathrm{z}}$ & $0.17 \mathrm{ab}$ & $2.42 \mathrm{a}$ & $1.77 \mathrm{ab}$ & $0.52 \mathrm{a}$ & $53 \mathrm{a}$ & $121 \mathrm{a}$ & $62 a$ & $22 b$ \\
\hline Halford & $2.50 \mathrm{a}$ & $0.20 \mathrm{a}$ & $2.49 \mathrm{a}$ & $1.86 \mathrm{a}$ & $0.55 \mathrm{a}$ & $67 a$ & $138 \mathrm{a}$ & $76 a$ & $41 \mathrm{a}$ \\
\hline Nemaguard & $2.51 \mathrm{a}$ & $0.16 \mathrm{~b}$ & $2.05 \mathrm{~b}$ & $1.69 \mathrm{a}$ & $0.42 b$ & $60 \mathrm{a}$ & $148 \mathrm{a}$ & $60 \mathrm{a}$ & $20 \mathrm{~b}$ \\
\hline Nemared & $2.39 \mathrm{a}$ & $0.16 \mathrm{~b}$ & $2.22 \mathrm{ab}$ & $1.45 \mathrm{~b}$ & $0.40 \mathrm{~b}$ & $68 \mathrm{a}$ & $144 \mathrm{a}$ & $57 \mathrm{a}$ & $27 \mathrm{~b}$ \\
\hline \multicolumn{10}{|c|}{$A U-R u b r u m$} \\
\hline Lovell & $2.05 \mathrm{~b}$ & $0.12 \mathrm{a}$ & $1.35 \mathrm{c}$ & $1.01 \mathrm{bc}$ & $0.29 \mathrm{ab}$ & $43 \mathrm{~b}$ & $101 \mathrm{a}$ & $55 \mathrm{a}$ & $21 \mathrm{a}$ \\
\hline Halford & $2.21 \mathrm{ab}$ & $0.14 \mathrm{a}$ & $1.83 \mathrm{~b}$ & $1.21 \mathrm{a}-\mathrm{c}$ & $0.36 \mathrm{a}$ & $67 \mathrm{~b}$ & $113 \mathrm{a}$ & $56 a$ & $19 \mathrm{a}$ \\
\hline Nemared & $2.46 \mathrm{ab}$ & $0.16 \mathrm{a}$ & $2.06 \mathrm{~b}$ & $1.41 \mathrm{a}$ & $0.38 \mathrm{a}$ & $54 \mathrm{~b}$ & $130 \mathrm{a}$ & $63 \mathrm{a}$ & $30 \mathrm{a}$ \\
\hline St. Julien & $2.51 \mathrm{a}$ & $0.16 \mathrm{a}$ & $2.44 \mathrm{a}$ & $1.29 \mathrm{ab}$ & $0.28 \mathrm{~b}$ & $105 \mathrm{a}$ & $116 a$ & 54 a & $33 \mathrm{a}$ \\
\hline Pixy & $2.24 \mathrm{~b}$ & $0.15 \mathrm{a}$ & $2.13 \mathrm{~b}$ & $0.99 \mathrm{c}$ & $0.23 \mathrm{~b}$ & $121 \mathrm{a}$ & $120 \mathrm{a}$ & $47 a$ & $29 a$ \\
\hline
\end{tabular}

${ }^{2}$ Means followed by the same letter within a column for a cultivar are not significantly different by Fisher's least significant difference at $P \leq 0.05$.
Table 3. Multiple regression results of foliar nutrient concentrations as predictors of shoot growth (1990 to 1993), increase in trunk cross-sectional area (TCA), and survivability. ${ }^{2}$

\begin{tabular}{lc}
\hline Variable & $\begin{array}{c}\text { Coefficient of } \\
\text { determination }\left(R^{2}\right)\end{array}$ \\
\hline Shoot growth $=$ & \\
$0.460 \mathrm{Mg}-0.210 \mathrm{Mn}$ & 0.324 \\
$\mathrm{TCA}=-0.487 \mathrm{Mn}+0.236 \mathrm{~B}$ & 0.338 \\
Survival $=$ & \\
$0.349 \mathrm{~N}+0.398 \mathrm{Ca}-$ & \\
$0.267 \mathrm{P}-0.360 \mathrm{Fe}$ & 0.296 \\
\hline
\end{tabular}

${ }^{2}$ Equations are adjusted so the constant (y-intercept) equals 0 .

\section{Literature Cited}

Baker, W.H. and T.L. Thompson. 1992. Determination of total nitrogen in plant samples by kjeldahl. Southern Coop. Serv. Bul. 368:13-16.

Childers, N.F. 1983. Modem fruit science. 9th ed. Horticultural Publications, Gainesville. Fla.

Cummins, J.N. and H.S. Aldwinckle. 1983. Rootstock breeding, p. 294-306. In: J.N. Moore and J. Janick (eds.). Methods in fruit breeding. Purdue University Press, West Lafayette, Ind.

Donohue, S.J. and D.W. Aho. 1992. Determination of $\mathrm{P}, \mathrm{K}, \mathrm{Ca}, \mathrm{Mg}, \mathrm{Mn}, \mathrm{Fe}, \mathrm{Al}, \mathrm{B}, \mathrm{Cu}$, and $\mathrm{Zn}$ in planttissue by inductively coupled plasma (ICP) emission spectroscopy, p. 37-40. In: C. Owen Plank (ed.). Plant analysis reference procedures for the southern region of the United States. Southern Coop. Serv. Bul. 368.

Dozier, W.A., Jr., et al. 1983. Rootstock influence on growth, yield, and survival of 'Loring' peach trees on an old peach site. J. Amer. Soc. Hort. Sci. 108:250-252.

Dozier, W.A., Jr., et al. 1984. Survival, growth, and yield of peach trees as affected by rootstocks. HortScience 19:26-30.

Hartmann, H.T. and D.E. Kester. 1975. Plant propagation: Principles and practices. 3rd ed. PrenticeHall, Englewood Cliffs, N.J.

Hesse, C.O. 1975. Peaches, p. 285-335. In: J. Janick and J.N. More (eds.). Advances in fruit breeding. Purdue Univ. Press, West Lafayette, Ind.

Knowles, J.W., W.A. Dozier, Jr., C.E. Evans, C.C. Carlton, and J.M. McGuire. 1984. Peach rootstock Influence on foliar and dormant stem nutrient content. J. Amer. Soc. Hort. Sci. 109:440-444.

Misic, P.D., V.Z. Pavlovic, R.R. Todorovic, and M.A. Mirkovic. 1990. Evaluation of vineyard Peach as a peach rootstock. Fruit Var. J. 44:99-102.

Okie, W.R. 1990. Ta Tao, P.I. 101686, affects bloom date and tree size of 'Sunprince' peach. Fruit Var. J. 44:87-89.

Reeves, D.W., H.J. Edwards, J.M. Thompson, and B.D. Horton, 1985. Influence of Ca concentration on micronutrient imbalances in vitro propagated Prunus rootstock. J. Plant Nutr. 8:289-302.

Rom, R.C. and R.F. Carlson (eds.). 1987. Rootstocks for fruit crops. Wiley, New York.

Sanchez-Alonso, F. and M. Lachica. 1987. Seasonal trends in the elemental content of plum leaves. Commun. Soil Sci. Plant Anal. 18:31-43.

Scholtens, A. and S.J. Wertheim. 1990. Niets beter bevonden dan St. Julien A. Op zoek naar een zwakke pruimeonderstam (1). Fruitteelt (Den Haag) 80:22-23.

Tabuenca, M.C. and M.A. Moreno. 1988 Incompatibili-dad entre patron e injerto. Comportamiento de un ciruelo coma patro de distintas especies frutales. Anales de la Estacion Experimental de Aula Det 19:251-263.

Westwood, M.N. 1993. Temperate-zonepomology. 2nd ed. W.H. Freeman \& Co., San Francisco.

Wilkinson, L., M. Hill, and E. Vang. 1992. Systat: Statistics, Version 5.2 ed. Systat, Evanston, Ill. 